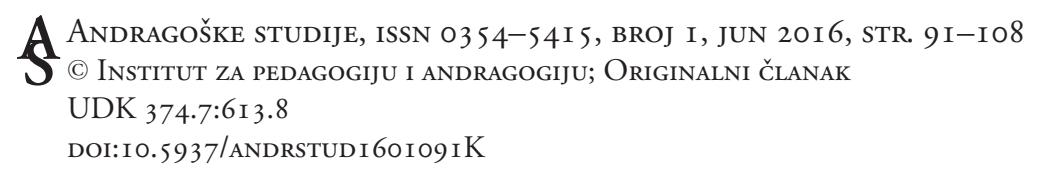

Mária Kispál Horváth ${ }^{1}$, Zsuzsa Mátrai ${ }^{2}$ University of West Hungary, Hungary

\title{
Adult Learning and Comfort Feeling
}

\begin{abstract}
The empirical research presented in this study focuses on the effects of formal and non-formal learning on learners' comfort feeling in the context of adult education. Offering an interpretation framework for data analysis, comfort feeling was divided into two parts: general and learning comfort feeling. Both notions were structured around the following dimensions: existential and mental aspects, time structure and social contacts. Additionally, learning comfort feeling contained a fifth dimension: knowledge. The results of the research are presented from three points of view. Firstly, we present our findings and data in the light of other international and Hungarian research concerning general comfort feeling. Secondly, we focus on the positive and negative effects of adult learners' formal and non-formal learning comfort feeling. Thirdly, we provide a description of the relationship between adults' general and learning comfort feeling.
\end{abstract}

Keywords: adult learning, general comfort feeling, learning comfort feeling.

\section{Concept and dimensions of comfort feeling}

Although numerous functions of adult education used to be listed in the professional literature, rapid changes have been occurring in macro-environment that could raise a new function, namely enhance of comfort feeling. It would be important the adults in our century because the fundamental changes in the economy and labour market significantly influence the way of life, thinking and mood of people. Presumably formal and non-formal adult learning could fortify the comfort feeling even in this uncertain and unaccountable world.

From this point of view, studying the Hungarian professional literature, we can find the concept of comfort feeling only in rare cases in some relation to adult learning. The only approach connected to the international literature is coming

\footnotetext{
1 Mária Kispál Horváth, PhD is the director of the Regional Pedagogical Service and Research Centre at the University of West Hungary, Hungary (kispalne.horvath.maria@nyme.hu).

2 Zsuzsa Mátrai, DSc is Professor Emerita at the University of West Hungary, Hungary (matrazsu@gmail. com).
} 
from Meleg who uses this concept as a synonym for well-being when presenting the personal and social comfort feeling as a part of confidence index referencing the research of New Economics Foundation (NEF),(Meleg, 2012). Since this is the approach of comfort feeling that is the closest one to our view we briefly describe the well-being model created by the NEF. The comfort feeling/wellbeing model consists of three components and numerous elements (Michaelson, Abdallah, Steuer, Thompson \& Marks, 2009; Michaelson, Mahony \& Schifferes, 2012) which are summarized in the Table 1.

Table 1: The main components and elements of comfort feeling/well-being model

\begin{tabular}{|c|c|c|c|c|c|c|c|}
\hline \multicolumn{5}{|c|}{ Personal } & \multicolumn{2}{|c|}{ social } & workplace \\
\hline emotional & $\begin{array}{l}\text { satisfaction } \\
\text { with life }\end{array}$ & vitality & $\begin{array}{l}\text { self-eva- } \\
\text { luation }\end{array}$ & $\begin{array}{l}\text { positive } \\
\text { operation }\end{array}$ & $\begin{array}{l}\text { supporting } \\
\text { relations }\end{array}$ & $\begin{array}{l}\text { confidence } \\
\text { and belon- } \\
\text { ging to }\end{array}$ & \\
\hline positive & & & & & & & \\
\hline emotions & & & optimism & competency & & & \\
\hline $\begin{array}{l}\text { lack of } \\
\text { negative } \\
\text { emotions }\end{array}$ & & & flexibility & $\begin{array}{l}\text { commitment } \\
\text { meaning and } \\
\text { aim of life }\end{array}$ & & & \\
\hline
\end{tabular}

Reports of the New Economics Foundation (with some modification in edition of table)

As we can see the personal comfort feeling is a complex component with five elements and three out of those have more sub-elements. The first element, emotional comfort, contains both the positive emotions (e.g. happiness, joy) and the lack of negative emotions (e.g. sadness, anxiety). The second is about satisfaction with life, and the third includes vitality (body recourses, physical activity, energetic and healthy way of life). The fourth element, self-evaluation, concentrates on self-esteem, optimistic vision about the future, and also flexibility concerning difficulties, problem-solving, and making decisions. The fifth one refers to the positive operation of a person among others including the autonomy. Its essence can be so articulated that the person should have possibility and time to do what he or she wants. The competency means the capabilities, and the commitment covers the will to learn and development. The last sub-element expresses how a person regards his or her life meaningful and valuable, and what kind of life aims they have specified.

The one of the elements of social comfort feeling is the supporting relations which could be defined by the extent and quality of relationships with the 
family members and friends, and the other people. The other element is confidence towards other people, and also belonging to somewhere.

The third component is the comfort feeling in the workplace which includes the satisfaction with job, working conditions, and balance between the job and private sphere in addition the joy, curiosity, and safety of a job.

By our perception the comfort feeling is also a complex umbrella concept. Regarding its essence and structure, it is very similar to the well-being construction by Martin Seligman (Seligman, 2011). The comfort feeling, like well-being, as a construction consists of components. In itself none of them determines the well-being or the comfort feeling influenced by adult learning but every component adds something measurable to the complex concept even if they are not absolutely correlated to each other.

In our research, comfort feeling was studied from two points of view: on one hand in general, in socio-economic context, and specifically, on the other hand, in the field of formal and non-formal adult education. Concerning the general comfort feeling, the existential and mental sense of security, the time structure and the social relations were regarded as dimensions (cf. components) that could be analysed in relation to comfort feeling. The studying of comfort feeling specifically in adult learning required a new dimension: knowledge, too. The questionnaires were planned on the basis of this model consisting of dimensions mentioned above and also, it was the conceptual framework for grouping data and research findings.

\section{Objectives, data resources, respondents of our research}

The key objective of the research was to map the impacts of formal and non-formal education on adult learners' comfort feeling in a complex way.

In order to realise the objectives we formulated the following research questions and hypotheses:

1. To what extent the indicators measuring the general comfort feeling in the examined population differ from Hungarian data presented in the international comparisons?

We assumed that the indicators measuring the general comfort feeling in the examined population will be similar to Hungarian data presented in the international comparisons.

2. In addition to the positive effects of learning, are there any negative impact on adults' comfort feeling? 
We assumed that learning had both positive and negative effects on the comfort feeling of participants in formal education, and only positive effects on adults participating in non-formal education.

3. Is learning related to adults' general comfort feeling in any way?

We presumed that our research would reveal some factors which show interdependence between learning and adults' general comfort feeling.

In the case of the respondents studying in Szombathely, the primary source of data was an adult education register. Eighty-three Szombathely-based institutions were listed in the register compiled in 2011. All of them were contacted in 2013 but only 43 institutions could be involved in the research, as the rest had not been providing training courses for at least two months.

The secondary sources of data were represented by two questionnaires: one for students in formal and one for students in non-formal education. The first part is identical in both questionnaires and-apart from some background questions - it relates to the dimensions of general comfort feeling mentioned above. The second, separate part of the questionnaires dealt with the connection between comfort feeling and adult learning in a formal or non-formal setting, and examined the effects of learning on the dimensions of comfort feeling. With the first version of the questionnaires we administered a trial test, and then refined and reworded some of the questions, or changed their order.

Data was processed using the IBM SPSS Statistics 20 programme. The quantitative results achieved with the mathematical-statistical methods included relative frequency distribution, arithmetic mean, contingency table analysis, correlation, cluster analysis.

Our empirical research can be regarded as a case study supported by the mathematical-statistical analysis of a relatively large amount of data. Empirical data obtained from the research also allows for drawing more general conclusions in cases where our results can be supported by data from other sources.

The group of respondents was carefully selected from adults who had been involved in formal or non-formal education for at least two months at the time of the empirical study. In the case of formal education, the group of respondents was limited to students studying in Szombathely, while in the case of non-formal education the geographical scope included Szombathely and other settlements in Vas County of West Hungary. The extension of geographical scope in the latter case was necessary to reduce inequalities between the respondents participating in the two types of training. 
In the spring of 2013, a total of 1,225 respondents were interviewed, including 875 persons participating in formal and 350 persons participating in non-formal education. Of the 350 persons, 245 studied in Szombathely and 105 in another settlement in Vas County. Thus, in total, the examined population comprises 1,120 persons studying in Szombathely and 105 persons studying in another settlement in Vas County. The number of surveyed persons and respondents is the same because they were contacted in person. The examined population covers the highly complex structure of adult education and training, because all segments of the system are represented (from adult education at secondary and tertiary level in schools through vocational and language courses to hobby clubs and artistic workshops). In addition, the examination attempted to involve all age groups of adults, including elderly people who are often excluded from surveys.

Pointing out the most important characteristic features of respondents we can say that two thirds of them are female, half of them are graduated in high school, most of them live in Vas County with their family, and half of them have one or two children. As far as the background data is concerned, the most significant differences between those involved in formal and non-formal education could be detected on the basis of age groups and-accordingly - in the age of children and in the proportion of active and inactive workers. When taking a closer look at age groups the most conspicuous difference is that while there is no insignificant number of elderly people in formal educational settings (only $4 \%$ are 50 years or over), non-formal settings for adult education include a larger number of them ( $42 \%$ are 50 years old or over; $15 \%$ are between $50-59$, and $27 \%$ are 60 years of age or older). In terms of family structure the most noticeable difference is that in formal settings the proportion of parents with a minor child is higher, while the majority of parents (68\%) involved in non-formal settings tend to have only adult children. As for respondents' status in the labour market, there are fewer inactive people among those in formal education $(29 \%$ are out of work) while $44 \%$ of those involved in non-formal education are inactive, twothirds of whom are retired.

46 percentage of adults opting for formal education are involved in vocational training (intellectual or physical, either grating a certificate issued on the basis of the National Training Register, 39\% study in higher education at a part-time course, $8 \%$ attend a course preparing them for a language exam and $7 \%$ attend a part-time course at a secondary school to obtain a school-leaving certificate.

The majority of those involved in non-formal education prefer hobby clubs, $32 \%$ attend such courses on a regular basis. The next most popular clubs and courses are those related to art, culture and sports with $23-23 \%$ of the re- 
spondents involved, respectively. A less significant proportion of the respondents (7\%) visit courses related to religion, $6 \%$ take part in life-coaching, also $6 \%$ go to foreign language courses not preparing for a language exam, while only $3 \%$ attend other work-related non-formal training.

\section{Respondents' general comfort feeling in light of international and national research findings}

By our first hypothesis we assumed that the indicators measuring adult students' general comfort feeling would be similar to Hungarian data presented in international comparison. The research, however, revealed that the general comfort feeling of respondents is slightly higher than what we anticipated on the basis of international and national research findings. The more positive overall outcome, however, does not mean that every dimension element was rated higher in the respondents' comfort feeling, but that there were no dimension elements with lower rates. In the following pages, we will analyse those dimensional elements which were similar or differed to positive directions. In our analysis, we will follow the structure of the well-being model used in the NEF mentioned before (Michaelson et al., 2009); we will present the individual elements along with adults' comfort feelings related to their personal, social sphere and to their workplace with the purpose of comparing the results with other national research findings.

As for the adult student's personal comfort feeling, our survey produced somewhat better results - on the whole and regarding specific elements - than the relevant figures of the international and national studies, the latter yielding fairly poor results. The latest well-being surveys i.e. the Map of Happiness (Medrano, 2009), the World Happiness Report (Helliwell, Layard \& Sachs, 2013), or the Happy Planet Index (Abdallah, Michaelson, Shah, Stoll \& Marks, 2012) administered during the past few years to explore people's happiness and satisfaction revealed that Hungary belonged to the less happy and satisfied countries ranking in the last third of the list. With these results we exceed only the former CIS countries and the states in the Balkans region. Similarly disheartening were the findings revealed by the NEF Study conducted in 22 countries where personal well-being was investigated as a complex multifaceted dimension and where Hungary ranked $20^{\text {th }}$.

As for first element of personal well-being, emotional comfort feeling which shows positive emotions and the lack of negative ones - Hungary came last in the NEF survey. A similar study was conducted by the ISES, the Institute for Social and European Studies Foundation, supported by the IBM, which focused on Hungarian work culture (Miszlivetz, 2009) drew a portrait of a very 
glum society, too. In contrast, at least two-thirds of our respondents experienced positive feelings such as happiness and high activity in our study. Out of the negative emotional elements, general anxiety is not as frequently experienced by our respondents except for their fear of an uncertain future, financial difficulties or health of their family members.

As for the second element of personal well-being, overall life satisfaction, Hungary occupies the $20^{\text {th }}$ place on the list of 22 countries involved in the NEF Study. In comparison, respondents living in Vas County seem to be relatively highly satisfied with the evolution of their life and also with their current life. Adult respondents showed dissatisfaction with their financial situation similarly to those questioned in the NEF Study. All things considered, adult learners are the least satisfied with their financial situation and their income, despite the fact that they rated these aspects to be of average importance. Their perception of existential difficulties is further demonstrated by another response with 53\% claiming that their living standards had decreased in the past few years while only $18 \%$ said that their standards had improved. There is also correspondence between the Gini Index, the most adequate measure of statistical dispersion intended to represent the income distribution of a nation's residents (United Nations Development Programme, 2009, 2011, 2013) and the responses provided by our adult learners. The latter gave a realistic picture of the differences between individual salaries: $20 \%$ thought the coefficient was 30\%, $42 \%$ put the figure even higher while 38\% thought the coefficient was lower (the Gini-index shows $30 \%$ ). A Hungarian study conducted on the same subject (Tóth, 2009) reveals that Hungarians tend to see the differences between salaries as even broader - but these results only partially coincide with our figures (in our survey $28 \%$ of the respondents estimated the difference to be 50 times higher).

If we investigate adult learners' satisfaction with indicators regarding gender, age, schooling, labour market status or financial situation, we can detect a considerable difference between the levels of satisfaction. Our results are in line with the findings of a study referred to as Hungarostudy Health Panel (Kopp, 2008). In general, women are more satisfied than men; those with a leaving examination certificate or degree are more content than those without, people with a job are happier than those on the dole, and the ones with improving living standards feel better than those whose living standards have been deteriorating. In terms of age, however, the level of satisfaction has revealed a mixed picture.

As for the third component of satisfaction, vigour and vitality we share the last place with another country in the NEF study. Here we looked at three features-subjective physical condition, physical activity and freshness after waking up-where the overall picture was more positive. Respondents were found most 
satisfied with their personal relationships, followed by their status of health and their physical status. Adult learners also highlighted the importance of sporting activities/excursions rating them third on a scale of 12 both in terms of priority and frequency. In contrast, only $35 \%$ of the respondents considered themselves moderately or fully relaxed after waking up in the morning.

Regarding the fourth element of personal well-being, self-evaluation —also made up of three traits: self-esteem, optimism and flexibility-Hungary was ranked one before the last in the NEF Study. Out of the two components measured in our survey, only one was found to give a somewhat more positive picture. Adult learners involved in our research have a higher self-esteem and fairly rarely suffer from anxiety. Their level of optimism, however, was found to be rather low and they also displayed a strong sense of insecurity. After their status of health, their next major concern was their future prospects which they deem highly dissatisfactory only to be followed by their financial situation and free time which rank at the bottom of the list. Adult learners are most worried about their own and their family's future prospects which again confirm their feeling of insecurity and their need for foresee ability. Our research finding — confirming respondents' sense of insecurity - is rather curious as there seems to be no difference of any kind between those with a job and those on the dole concerning the level of anxiety over their uncertain future. Our research discoveries focusing on people's general feeling of uncertainty seem to be in line with both the International NEF survey and the Hungarian HEP Study which highlight that security and predictability are highly important to Hungarian adults.

The fifth component of personal well-being is positive functioning, and with its $10^{\text {th }}$ place Hungary is in mid-field position in the NEF Study. Our research appears to confirm these results as our respondents possess all the components that serve as prerequisites for positive functioning. In terms of respondents' purpose of life, internal ones dominate over external purposes and, accordingly, leading a sensible and valuable life ranks very high among the subjects. External purposes of life such as wealth, power or fame are regarded as more important by males, by those below 30 , by those with lower qualifications and by unemployed people. Our research concerning the purpose of life seem to be in line with the findings of the HEP Study and the ISES research; there is only one indicator that goes against the HEP Study: among the adult learners involved in our study external purposes of life appear to be stronger for those in improving financial conditions. Another component of positive functioning, i.e. the commitment to learning and development is present in our respondents across the board due to the various learning motivations they have. Next component is the individuals' autonomy, which can be explored in the context of the frequency and priority of 
free time activities. Based on these findings, we could detect some autonomy in the adults' life as their rating order — in terms of the frequency and importance of free time activities - shows a high degree of similarity.

As for the respondents' social well-being, the situation appears to be somewhat more positive in comparison with other research findings. The NEF survey revealed that Hungarian people's general social well-being is higher (it ranks $11^{\text {th }}$ ) in comparison with their general personal well-being described above (on the $20^{\text {th }}$ place). But while within the category of social well-being concerning two components (i.e. trust and sense of belonging) we rank $4^{\text {th }}$ and $5^{\text {th }}$; regarding the third component (social support) we share the lowest place in the list together with the Ukraine. Our research investigated the latter and it was found that our adult learners' social support was significantly stronger both in terms of quality and quantity in comparison with those involved in the NEF Study. For instance, out of the 1,219 respondents only 11 claimed they had no one to rely on in times of trouble, and over $70 \%$ of them have four or more people to turn to in a distressing situation. These results seems to be confirmed by the respondents' general satisfaction with their human relationships, and the fact that their favourite free time activity was the time spent with their friends and family one the one hand, and that they were the least concerned about conflicts in their family, on the other hand.

Respondents currently in employment also showed a higher level of workplace well-being than the Hungarians involved in the NEF Study. In this international study conducted in 22 countries to investigate satisfaction with one's job and salary, happiness at work and the chances of becoming unemployed, Hungary ranked $17^{\text {th }}-18^{\text {th }}$. Employees involved in our study viewed all of the components rather positively (their safety of work, happiness, working conditions, loyalty, the management's commitment and their sense of control) except for one element: their salary. For instance, $84 \%$ of the respondents enjoy doing their job, $83 \%$ feel committed or highly committed to their workplace; $74 \%$ regard their working conditions reasonably or highly satisfactory, and $72 \%$ claim they have a secure job. These results seem to be coinciding with the findings of the Hungarian ISES research, e.g. in terms of happiness at work, the feeling of job security, loyalty to their workplace, and their general dissatisfaction with their current salary.

On the whole, our results have both overlaps and discrepancies when compared with the findings of other national and international studies. Here are the components where our adult learner respondents depicted a more positive picture: they have a higher level of positive emotions, they are generally more satisfied with their life, they are more self-confident, exhibit a higher degree of vitality; they have a better sense of social support, greater happiness at work and a lower level of anxiety. 
In the followings, we shall list the components of comfort feeling where we registered a correlation between the ones provided by our adult learners, and by other Hungarian respondents involved in national and international studies: a sense of existential and general uncertainty, a lower level of optimism, but an adequate level of positive functioning (a dominance of internal purpose of life, commitment to further development, autonomy).

These comparative data seem to be even more thought-provoking in light of the fact that each of the three studies quoted above had been conducted before or during the financial recession of 2008 (HEP in 2006, NEF in 2007 and ISES in Autumn, 2008). One would expect some deterioration or at least a high degree of similarity between the responses in some of the major issues related to workplace well-being or the general satisfaction with life, but one would hardly anticipate more positive picture. These findings cannot be accounted for with statistical devices and further empirical research would be necessary to find some proper explanations for the above discoveries.

\section{Positive and negative impacts of adult learning on comfort feeling}

Our second hypothesis assumed that learning had both positive and negative effects on the comfort feeling of participants in formal education, and only positive effects on adults participating in non-formal education. All in all, based on the research findings concerning the impacts of adult learning on comfort feeling it may be established that the positive effects outweigh the negative ones in both forms of education, but while formal education feature has some substantial negative effects, in non-formal education the negative effects are negligible. In the followings, we shall apply various dimensions to compare the positive and negative impacts exerted by adult learning on the comfort feeling of those involved in formal and non-formal education settings.

\section{Existential sense of security}

Logically, this dimension was examined in detail only with respect to participants in formal adult education which made any meaningful comparison between the two forms of learning pointless. The strongest motives among students opting for formal education settings were existential ones, but the positive impact on the quality of work was also notable. In contrast, half of the adults participating in formal education found it difficult to finance their studies, and therefore experienced a negative impact on their sense of existential security. 


\section{Mental sense of security}

Positive effects on the mental sense of security are much stronger than negative ones in both forms of learning. Although the positive effects slightly varied between the two groups, three out of the five strongest positive effects were identical, namely: wider intellectual horizon, sense of achievement and increased persistence. Further positive effects include, in the case of formal education, assuming a wider range of roles, positive feedback from the family, more confidence in voicing opinions and renewed optimism; while in the case of non-formal education, a more positive view of life, forgetting about daily difficulties and increased self-confidence.

Negative effects deteriorating the mental sense of security are stronger among students in formal education settings. From the 14-14 partly different reasons of anxiety, selected by us, at least half of the respondents in formal settings indicated the presence of five such reasons, and only one did so in a nonformal setting. Students in formal settings are mostly affected by anxiety caused by tests, preparatory periods, time pressure, commitments and weak performance, while non-formal education students were only worried about weak performance. Those involved in non-formal education quite clearly wanted to comply with the requirements only for their own sake while those involved in formal settings felt a more compelling need for compliance.

\section{Time structure}

One of the most important positive effects of learning on adults' time-frame is the feeling of spending free time meaningfully, which is a much more significant learning motive for non-formal education students. For this group it ranks $2^{\text {nd }}$ from among the 23 motives while in the case of formal students it ranks $11^{\text {th }}$ out of 17 such motives. Half of the respondents participating in formal adult education experienced improved time management, and $70 \%$ of non-formal education students spent more time on leisure activities such as enjoying the company of friends, attending cultural events, being involved in creative activities and reading books.

Major negative impacts on the time structure include less free time for three-fourth of formal education students. In both forms of learning, the greatest sacrifice for students is the reduced amount of time with family and friends. Another negative impact — especially for students in formal settings—is that they have to do a great portion of their home assignments in the evening or at night. 


\section{Social relationships}

Here the most significant positive effect of learning is the expansion of social capital which is reflected in both formal and non-formal education in making new social relationships mostly related to respondents' learning activities. Most respondents expect some of these new relationships built with their peers to last in the long run. Another positive impact might be that both types of learners enjoy considerable support from their family. As a negative effect in-group conflicts appear in both forms of education in an identical proportion. The most frequent source of conflict is the lack of reciprocity in formal education and lack of cooperation in non-formal education. Formal education students experience more family conflicts because of their studies than non-formal education students. For non-formal students the most frequent source of conflict is the reduced amount of time spent with the family and the decreasing amount of household chores they can carry out. These are pressing problems for those in formal settings as well, moreover, adults learners tend to become more irritated and conflicts are more likely to be caused as a result of financial difficulties mostly because of high tuition fees.

\section{Knowledge}

In respect of this dimension, non-formal education students appear to be in an ideal situation as their needs largely correspond to the characteristics of their courses, which can be regarded as positive. In contrast, formal education students sometimes experience substantial discrepancies between their expectations and actual course characteristics, in particular regarding practical knowledge, labour market competences, student-friendly approach, stress-free learning environment and examination methods - which can be evaluated as negative. ${ }^{3}$

All things considered, for both types of learning settings positive impacts were more pronounced in terms of three dimensions we referred to as mental sense of security, social relationships and knowledge. Besides, we can highlight further positive effects such as formal students' existential sense of security both

\footnotetext{
3 There are both similarities and differences in the raking of the expectation held by those involved in formal and non-formal adult learning settings. Out of the five most important expectations there are three elements that both groups highlighted: the need for adequately prepared instructors and their appreciation of help and practice-centred training opportunities. Formal students also stressed the significance of proper information exchange and their wish to should be tested with focus on their real knowledge. Non-formal students pointed out the importance of a good atmosphere and the acquisition of skills they can use in everyday situations.
} 
in the present and in the future, and non-formal students' perception of positive effects made on their time structure (i.e. especially their free time). There are also negative effects sensed by formal students in terms of their existential sense of security (i.e. financial problems during their studies), regarding their mental sense of security (anxiety and a pressure for compliance) and concerning the time structure (time press because of the multitude of commitments).

\section{Factors of interdependence between learning and general comfort feeling: motivation and satisfaction}

Our third hypothesis assumed that the research would reveal some factors which show interdependence between learning and adults' general comfort feeling. From the perspective of learning motivation and from the perspective of general comfort feeling satisfaction was found to be the factor which can prove the reciprocity assumed in the third hypothesis. The interdependence mentioned above could be verified in the following two tables. The first shows the results of comparison between the formal learning and general clusters, and the second between the nonformal learning and general clusters pointing out the motivation and satisfaction.

Table 2: Motivation and satisfaction between formal learning and general clusters

\begin{tabular}{|c|c|c|c|c|c|c|c|}
\hline & \multicolumn{6}{|c|}{ GENERAL CLUSTERS } \\
\hline & & $\begin{array}{l}\text { dissatisfied } \\
N=402\end{array}$ & $\begin{array}{l}\text { rather } \\
\text { dissatisfied } \\
\mathrm{N}=60\end{array}$ & $\begin{array}{l}\text { rather } \\
\text { satisfied } \\
\mathrm{N}=142\end{array}$ & $\begin{array}{l}\text { satisfied } \\
N=152\end{array}$ & $\begin{array}{l}\text { dissatisfied } \\
\text { and rather } \\
\text { dissatisfied } \\
\mathrm{N}=462\end{array}$ & $\begin{array}{l}\text { satisfied } \\
\text { and rather } \\
\text { satisfied } \\
\mathrm{N}=294\end{array}$ \\
\hline \multirow{5}{*}{ 胥是 } & $\begin{array}{l}\text { not very } \\
\text { motivated } \\
\mathrm{N}=247\end{array}$ & $57,5 \%$ & $6,5 \%$ & $16,6 \%$ & $19,4 \%$ & $64 \%$ & $36 \%$ \\
\hline & $\begin{array}{l}\text { coercively } \\
\text { motivated } \\
\mathrm{N}=30\end{array}$ & $43,3 \%$ & $26,7 \%$ & $10 \%$ & $20 \%$ & $70 \%$ & $30 \%$ \\
\hline & $\begin{array}{l}\text { extrinsically } \\
\text { motivated } \\
N=304\end{array}$ & $57,6 \%$ & $9,2 \%$ & $20,1 \%$ & $13,2 \%$ & $67 \%$ & $33 \%$ \\
\hline & $\begin{array}{l}\text { intrinsically } \\
\text { motivated } \\
N=175\end{array}$ & $41,1 \%$ & $4,6 \%$ & $21,1 \%$ & $33,1 \%$ & $46 \%$ & $54 \%$ \\
\hline & $\begin{array}{l}\text { total formal } \\
\text { cluster } \\
N=756\end{array}$ & $53,2 \%$ & $7,9 \%$ & $18,8 \%$ & $20,1 \%$ & $61 \%$ & $39 \%$ \\
\hline
\end{tabular}


Table 3: Motivation and satisfaction between non-formal learning and general clusters

\begin{tabular}{|c|c|c|c|c|c|c|c|}
\hline & \multicolumn{6}{|c|}{ GENERAL CLUSTERS } \\
\hline & & $\begin{array}{l}\text { dissatisfied } \\
N=113\end{array}$ & $\begin{array}{l}\text { rather } \\
\text { dissatisfied } \\
\mathrm{N}=62\end{array}$ & $\begin{array}{l}\text { rather } \\
\text { satisfied } \\
\mathrm{N}=63\end{array}$ & $\begin{array}{l}\text { satisfied } \\
\mathrm{N}=82\end{array}$ & $\begin{array}{l}\text { dissatisfied } \\
\text { and rather } \\
\text { dissatisfied } \\
N=175\end{array}$ & $\begin{array}{l}\text { satisfied } \\
\text { and rather } \\
\text { satisfied } \\
\mathrm{N}=145\end{array}$ \\
\hline \multirow{5}{*}{ 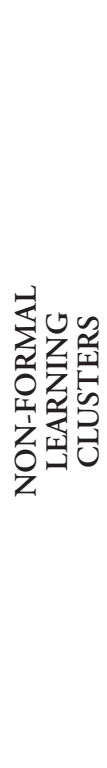 } & $\begin{array}{l}\text { those } \\
\text { spending } \\
\text { time only } \\
\mathrm{N}=43\end{array}$ & $39,5 \%$ & $23,3 \%$ & $9,3 \%$ & $27,9 \%$ & $63 \%$ & $37 \%$ \\
\hline & $\begin{array}{l}\text { those } \\
\text { seeking } \\
\text { company } \\
\mathrm{N}=32\end{array}$ & $40,6 \%$ & $40,6 \%$ & $9,4 \%$ & $9,4 \%$ & $81 \%$ & $19 \%$ \\
\hline & $\begin{array}{l}\text { those } \\
\text { seeking } \\
\text { occupation } \\
\mathrm{N}=113\end{array}$ & $37,2 \%$ & $15,9 \%$ & $17,7 \%$ & $29,2 \%$ & $53 \%$ & $47 \%$ \\
\hline & $\begin{array}{l}\text { those } \\
\text { seeking } \\
\text { self-deve- } \\
\text { lopment } \\
\mathrm{N}=132\end{array}$ & $31,1 \%$ & $15,9 \%$ & $27,3 \%$ & $25,8 \%$ & $47 \%$ & $53 \%$ \\
\hline & $\begin{array}{l}\text { total non- } \\
\text { formal } \\
\text { cluster } \\
\mathrm{N}=320\end{array}$ & $35,3 \%$ & $19,4 \%$ & $19,7 \%$ & $25,6 \%$ & $55 \%$ & $45 \%$ \\
\hline
\end{tabular}

Comparing general and learning (formal and non-formal) clusters, we can make two important statements. First, on the whole, in both formal and nonformal groups, the number of dissatisfied students is the highest, but the figure is higher in the formal group (61\%) than in the non-formal group (55\%). Secondly, in both formal and non-formal groups, there is a cluster of satisfied/rather satisfied students, namely intrinsically motivated students in the formal group and self-developers in the non-formal group.

A high level of similarity was found between intrinsically motivated students and students seeking self-development not only in terms of their higher general comfort feeling but also in terms how their formal/non-formal learning effected their comfort feeling as the figure 1 and 2 presents below. 

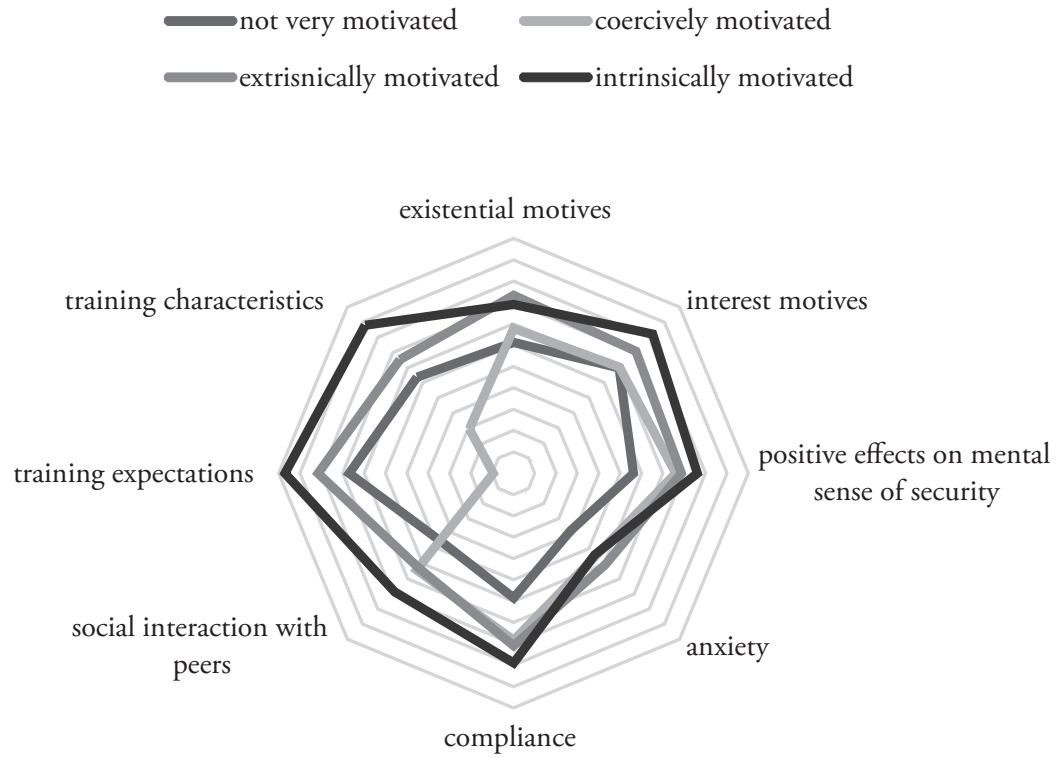

Figure 1: Most important features of formal learning clusters

$\begin{array}{ll}\text { those only spending time } & \text { those seeking company } \\ \text { those seeking an occupation } & \text { those seeking self-development }\end{array}$

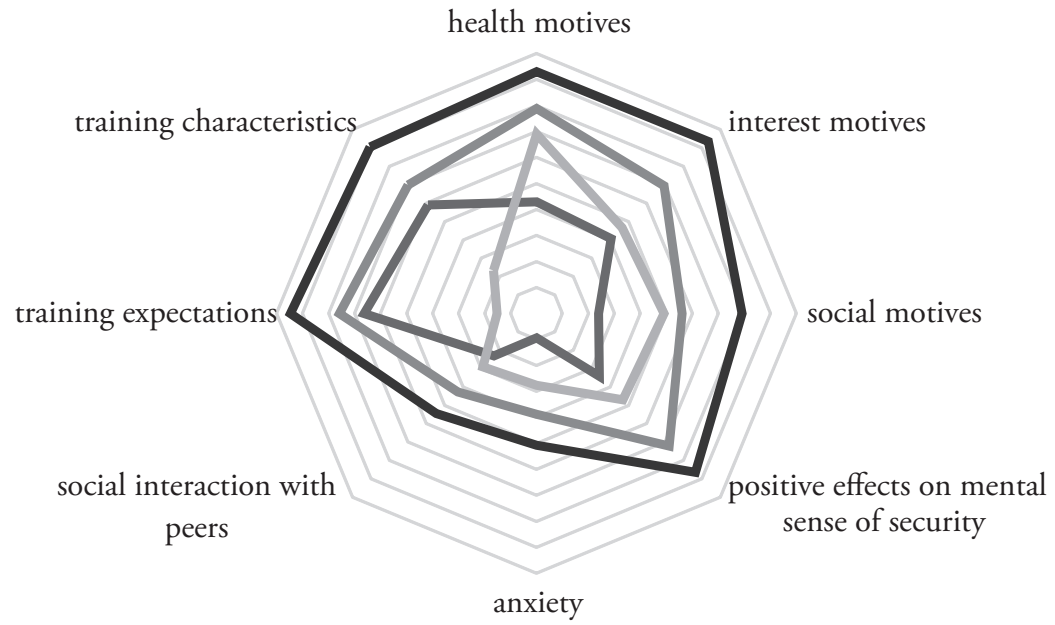

Figure 2: Most important features of non-formal learning clusters 
In the two figures one can see four different colours indicating the relations to the 8-8 aspects of the 4-4 clusters members expressing on a $1-4$ scale. A positive deviation was noticed when the intrinsically motivated students and the ones seeking self-development were compared with other formal and nonformal clusters. The former two groups showed the highest degree of motivation, especially in terms of interests and social motives. It is the same two groups that revealed the strongest positive effects exerted on their mental sense of security. They have the highest expectations about adult education and they view their own training schemes in the most positive way. The most negative deviation is that those belonging to the two most positive clusters appear to be most frequently anxious. Intrinsically motivated students are more anxious than the average and those seeking self-development are the most anxious ones.

\section{Summary}

Generally on the basis of our research findings (the following conclusion) could be drawn: in the present economic and social circumstances, in the uncertain world the adult learning is a good investment and also increases the comfort feeling of adults. This conclusion is proved since the learning adults have higher general comfort feeling, there are much more positive impacts of learning than negative ones especially with those who attend non-formal education and who have strong intrinsic motivation for learning. Our findings meet recommendations of the New Economic Foundation elaborated by more than 400 scholars in an interdisciplinary project in favour of well-beings'/comfort feelings' increase. In conclusion their five recommendations are as follows: connect, be active, take notice, keep learning, give! (Michaelson at al, 2009) All of these are in direct or indirect connection with different forms of adult learning and easily associated with our proposed new function of adult education that aims at the increase of comfort feeling.

\section{References}

Abdallah S., Michaelson J., Shah S., Stoll L., \& Marks N. (2012). The Happy Planet Index: 2012 Report. A global index of sustainable well-being. London: New Economics Foundation. Retrieved from https://static1.squarespace.com/ static/5735c421e321402778ee0ce9/t/578de9dd29687f525e004f1d/146891824 1593/2012+Happy+Planet+Index+report.pdf 
Helliwell, J., Layard, R., \& Sachs, J. (2013). World Happiness Report. Retrieved from http://unsdsn.org/wp-content/uploads/2014/02/WorldHappinessReport2013_ online.pdf

Kopp, M. (2008). Az esélyerősítés magatartástudományi modellje [A behavioral model for empowerment]. In M. Koppm(Ed.), Magyar lelkiállapot 2008. (Hungarian state of mind 2008.) Budapest: Semmelweis Kiadó.

Medrano, J. D. (2009). Map of happiness. Retrieved from http://www.jdsurvey.net/jds/ jdsurveyActualidad.jsp? Idioma $=\mathrm{I} \&$ Seccion Texto $=0404 \&$ NOID $=103$

Meleg, C. (2012). A bizalom hálójában - társadalmi nézöpontok [The web of trust - social aspects.]. JURA. 1.

Michaelson, J., Abdallah, S., Steuer, N., Thompson, S., \& Marks, N. (2009). National Accounts of Well-being. Bringing real wealth onto the balance sheet. London: New Economics Foundation. Retrieved from http://www.nationalaccountsofwellbeing.org/public-data/files/national-accounts-of-well-being-report.pdf

Michaelson, J., Mahony, S., \& Schifferes, J. (2012). Measuring Well-being. A guide for practitioners. London: New Economics Foundation. Retrieved from http://dnwssx417gl7s.cloudfront.net/nefoundation/default/page/-/files/Measuring_wellbeing_handbook_FINAL.pdf

Miszlivetz, F. (2009). A magyar munkakultúra állapota és alakitásának lehetösége globális környezetben [The state of Hungarian work culture and forming possibilities in the global environment.]. Szombathely: Savaria University Press.

Olám, A., \& Kapitány-Föveny, M. (2012). A pozitív pszichológia tíz éve [Ten years of positive psychology]. In: A. Oláh (Ed.), A pozitiv pszichológia világa [The world of positive psychology]. Budapest: Akadémiai Kiadó.

Seligman, M. (2011). What is well-being? Authentic happiness. Retrieved from https:// www.authentichappiness.sas.upenn.edu/learn/wellbeing

То́тн, I., G. (2009). Bizalomhiány, normazavarok, igazságtalanságérzet és paternalizmus a magyar társadalom értékszerkezetében [Lack of trust, norm disorders, sense of injustice $d$ paternalism in the value structure of Hungarian society]. Budapest: Társadalomkutatási Intézet.

RETRIEVED FROM HTTP://www.TARKI.HU/HU/RESEARCH/GAZDKULT/GAZDKULT_ELEMZESZARO_TOTH.PDF

United Nations Development Programme (UNDP) (2009). Human Development Report 2009. Overcoming barriers: Human mobility and development. Retrieved from http://hdr.undp.org/sites/default/files/reports/269/hdr_2009_en_complete.pdf

United Nations Development Programme (UNDP) (2011). Human Development Report 2011. Sustainability and Equity: A Better Future for All. Retrieved from http://hdr.undp.org/sites/default/files/reports/271/hdr_2011_en_complete.pdf

United Nations Development Programme (UNDP) (2013). Human Development Report 2013. The Rise of the South: Human Progress in a Diverse World. Retrieved from http://hdr.undp.org/sites/default/files/reports/14/hdr2013_en_complete.pdf 
Mária Kispál Horváth ${ }^{4}$, Zsuzsa Mátrai ${ }^{5}$

Univerzitet u zapadnoj Mađarskoj, Mađarska

\section{Učenje odraslih i osećaj ugodnosti}

Apstrakt: Empirijsko istraživanje predstavljeno u ovoj studiji ima kao fokus efekte formalnog i neformalnog učenja na osećaj ugodnosti učenika u kontekstu obrazovanja odraslih. Nudeći interpretacioni okvir za analizu podataka, osećaj ugodnosti je podeljen u dva dela: opšti osećaj ugodnosti, i osećaj ugodnosti pri učenju. Oba koncepta su struktuirana na osnovama sledećih dimenzija: egzistencijalni aspekti, mentalni aspekti, vremenska struktura, i društveni kontakti. Uz ovo, osećaj ugodnosti pri učenju je imao i petu dimenziju: znanje. Rezultati istraživanja su predstavljeni iz tri perspektive. Pvo, predstavljamo naše podatke i nalaze u svetlu drugih međunarodnih i mađarskih istraživanja u vezi sa opštim osećajem ugodnosti. Na drugom mestu, fokusiramo se na pozitivne i negativne efekte na osećaj ugodnosti pri formalnom i neformalnom učenju kod učenika. Na trećem mestu, dajemo opis odnosa između opšteg osećaja ugodnosti i osećaja ugodnosti pri učenju kod odraslih.

Ključne reči: učenje odraslih, opšti osećaj ugodnosti, osećaj ugodnosti pri učenju.

\footnotetext{
${ }^{4}$ Dr Mária Kispál Horváth je direktorka projekta Regionalne pedagoške službe i Istraživačkog centra, Univerzitet u zapadnoj Mađaraskoj, Mađarska.

${ }^{5}$ Dr Zsuzsa Mátrai je profesor emeritus na Univerzitetu u zapadnoj Mađarskoj, Mađarska.
} 